\title{
A Ação CIVIL Pública E A TUTELA DOS DIREITOS INDIVIDUAIS HOMOGÊNEOS EM MATÉRIA DE SEgURIDAdE SOCIAL
}

\section{Cristhian Magnus de Marco}

Mestre em Instituições Jurídico Políticas pela UFSC. Doutorando em Direito na PUC-RS.

Professor e Pesquisador da Universidade do Oeste de Santa Catarina. Advogado.

\section{Katiane SANDRIN}

Bacharel em Direito pela Universidade do Oeste de Santa Catarina. Bolsista do Programa Institucional de Bolsas de Iniciação Científica da Universidade do Oeste de de Santa Catarina.

ÁreA do Direito: Constitucional

Resumo: 0 presente artigo analisa as possibilidades da Ação Civil Pública em matéria de Direitos Sociais, restringindo-se aos aspectos concernentes à Seguridade Social. Com efeito, a utilização da Ação Civil Pública no âmbito do Poder Judiciário brasileiro vem mostrando alguns avanços, isto é, abrindo-se para a inclusão de novas matérias de tutela jurisdicional coletiva. Nesse passo, mostra-se que eventual conceituação dos direitos individuais homogêneos deve ser sempre provisória, viabilizando sempre possibilidades de acordo com as necessidades novas para que se assegure a dignidade humana. As recentes decisões do STF e do STJ são importantes. Passaram a admitir a revisão de benefícios previdenciários
ABSTRACT: This article examines the possibilities of Ação Civil Pública in the field of Social Rights, restricted to the aspects concerning Security Social. Indeed, the use of Ação Civil Pública under the Brazilian judiciary has shown some progress, that is opening itself to the inclusion of new materials of judicial conference. In this step, we show that any concept of Rights Homogeneous Individual must always be provisional, enabling always possibilities according to new requirements to ensure that the dignity human. The recent decisions of the Supreme Court and the Superior Court are important. They began to admit to review benefits of social security by Ação Civil Pública, considering as a matter of individu- 
em Ação Civil Pública, considerando a matéria como de direito individual homogêneo, tutelado sempre que houver "relevante interesse social". Essa ampliação mostra-se fruto de uma interpretação evolutiva dos direitos sociais e tendente à proteção jurisdicional mais efetiva dos mesmos.

Palavras-chave: Ação Civil Pública - Interesses individuais homogêneos - Seguridade Social Direitos Sociais. al right homogeneous protected whenever there are "social interest". This inset shows is the result of an evolutionary interpretation and social rights designed to protect court most effective of them.

KeYwords: Public Civil Suit - Homogeneous Individual Rights - Social Security - Social Rights.

SumÁrı: 1. Introdução - 2. Da Ação Civil Pública - 3. Direitos ou interesses tuteláveis em Ação Civil Pública: 3.1 Direitos Sociais tutelados pela Ação Civil Pública; 3.2 Legitimados ativos da Ação Civil Pública - 4. Precedentes em matéria de Ação Civil Pública para a proteção de Direitos Sociais Individuais Homogêneos - 5. Conclusão - 6. Bibliografia.

\section{INTRODUÇÃO}

O presente texto apresenta alguns aspectos do Direito brasileiro que dizem respeito à tutela dos Direitos Individuais Homogêneos no âmbito da Seguridade Social, por meio da Ação Civil Pública.

A Seguridade Social ${ }^{1}$ compreende, no Brasil, os âmbitos da saúde ${ }^{2}$ previdência social ${ }^{3}$ e assistência social. ${ }^{4}$ As normas da Constituição Federal

1. Art. 194 da CF/1988: "A seguridade social compreende um conjunto integrado de ações de iniciativa dos Poderes Públicos e da sociedade, destinadas a assegurar os Direitos relativos à saúde, à previdência e à assistência social".

2. Art. 196 da CF/1988: "A saúde é direito de todos e dever do Estado, garantido mediante políticas sociais e econômicas que visem à redução do risco de doença e de outros agravos e ao acesso universal e igualitário às ações e serviços para sua promoção, proteção e recuperação".

3. Art. 201 da CF/1988: "A previdência social será organizada sob a forma de regime geral, de caráter contributivo e de filiação obrigatória, observados critérios que preservem o equilíbrio financeiro e atuarial, e atenderá, nos termos da lei (...)".

4. Art. 203 da CF/1988: "A assistência social será prestada a quem dela necessitar, independentemente de contribuição à seguridade social, e tem por objetivos:

I - a proteção à família, à maternidade, à infância, à adolescência e à velhice;

II - o amparo às crianças e adolescentes carentes;

III - a promoção da integração ao mercado de trabalho;

IV - a habilitação e reabilitação das pessoas portadoras de deficiência e a promoção de sua integração à vida comunitária; 
brasileira, com efeito, geram direitos ${ }^{5}$ e obrigações ${ }^{6}$ nessas três dimensões.

Por Direitos Individuais Homogêneos devem ser entendidos aqueles próprios de uma coletividade que, apesar de seus membros poderem ser identificados e lhes ser facultado o exercício individual da tutela jurisdicional dos seus Direitos, devido ao grande interesse público da matéria em questão, abre-se a alternativa de tutela coletiva do Direito, por meio de instrumentos processuais próprios previstos em lei, especialmente através da Ação Civil Pública. ${ }^{7}$

Considerando que o exercício coletivo de Direitos é matéria nascida há pouco no Direito Constitucional e Processual brasileiro, torna-se importante o registro dos principais avanços nos âmbitos da efetividade social, dos precedentes jurisprudenciais e da dogmática doutrinária.

\section{Da Ação CiVIL PÚblicA}

A justicialização dos interesses difusos, coletivos e individuais homogêneos começou a ganhar destaque a partir do momento em que a tutela de tais interesses, por meio de um processo individual, mostrou-se insuficiente. O Código de Processo Civil vigente, em seu art. 6. ${ }^{\circ}$, expressa que ninguém poderá pleitear, em nome próprio, Direito alheio, salvo quando autorizado por lei.

A exceção prevista no dispositivo supracitado é a legitimação extraordinária (art. $6 .^{\circ}$, in fine, do CPC), que ocorre quando a lei especialmente concede a

V - a garantia de um salário mínimo de benefício mensal à pessoa portadora de deficiência e ao idoso que comprovem não possuir meios de prover à própria manutenção ou de tê-la provida por sua família, conforme dispuser a lei".

5. O presente trabalho segue alguns pressupostos a partir de Robert Alexy: "se um direito [social] existe, ele é justiciável" (Alexy, 2008, p. 514).

6. Não obstante a justiciabilidade dos Direitos Sociais, Canotilho escreve que as normas constitucionais consagradoras de Direitos Econômicos, Sociais e Culturais, possuem uma dimensão objetiva dos Direitos Fundamentais que atuam de duas formas: (1) imposições legiferantes; e (2) fornecimento de prestações ao cidadão (CANotilho, 2011, p. 476). Mas, sempre é bom constar a frase incisiva de Alexy (2008, p. 514): "um tribunal constitucional não é, de modo algum, impotente em face de um legislador omisso". Por isso o autor defende que, em face da esfera objetiva de princípios constitucionais, pode ocorrer uma subjetivação de direitos e deveres por meio da natureza principiológica dos Direitos Fundamentais (AleXY, 2008, p. 455).

7. O manuseio de conceitos deve ser visto aqui como uma tentativa de redução das complexidades interpretativas inerentes ao uso da linguagem, porém, sem a ilusão de apreensão total da realidade. 
faculdade para que alguém, em nome próprio, exerça ação em favor do Direito de terceiro(s).

Contudo, a legitimação extraordinária não é suficiente para regular Direito ou interesse difuso, coletivo ou individual homogêneo, porque o Código de Processo Civil não dispõe de tais mecanismos processuais. Assim, se uma pessoa ou entidade visasse propor uma demanda com o objetivo de tutelar um Direito ou interesse difuso, coletivo ou individual homogêneo, com base unicamente no Código de Processo Civil, o processo seria forte candidato a ser extinto sem julgamento do mérito, diante da ausência de uma das condições da ação (art. 267, VI, do CPC). ${ }^{8}$

Por isso, a Lei 7.347/1985, que regulamentou essa nova espécie de ação judicial, permite a tutela de tais interesses por meio de um substituto processual conforme será visto com mais detalhes a seguir.

A Lei da Ação Civil Pública simboliza um marco para a ampliação do acesso à justiça, pois que abriu a possibilidade de se postular em juízo a tutela dos interesses metaindividuais. Vale praticar, destarte, uma releitura do art. $3 .^{\circ}$ do CPC, ${ }^{9}$ substituindo-se a visão processualista/formalista, por outra que atenda às necessidades de uma sociedade de massa.

A Ação Civil Pública densifica o princípio da economia processual, uma vez que tende a evitar decisões contraditórias dos órgãos jurisdicionais para fatos com mesmos pedidos e/ou causa de pedir, tendo em vista que a tutela desse instrumento jurídico é ampla, viabilizando a proteção coletiva de Direitos. ${ }^{10}$

8. “Art. 267. Extingue-se o processo, sem resolução de mérito:

(...)

VI - quando não concorrer qualquer das condições da ação, como a possibilidade jurídica, a legitimidade das partes e o interesse processual;"

9. "Art. 3. Para propor ou contestar ação é necessário ter interesse e legitimidade."

10. "É preciso, pois, que não se confunda defesa de Direitos Coletivos com Defesa Coletiva de Direitos (Individuais). Direitos Coletivos são Direitos subjetivamente transindividuais (sem titular determinado) e materialmente indivisíveis. Os Direitos Coletivos comportam sua acepção no singular, inclusive para fins de tutela jurisdicional. Ou seja: embora indivisível, é possível conceber-se uma única unidade da espécie de Direito Coletivo. O que é múltipla (e indeterminada) é a titularidade, e daí a sua transindividualidade. 'Direito Coletivo' é designação genérica para as duas modalidades de Direitos Transindividuais: o Difuso e o Coletivo stricto sensu. É denominação que se atribui a uma especial categoria de Direito Material, nascida da superação, hoje indiscutível da tradicional dicotomia entre interesse público e interesse privado. É Direito que não pertence a Administração Pública e nem a indivíduos particularmente determinados. Pertence, sim, a um grupo de pessoas, a uma classe, a uma categoria, 
A par disso, é imprescindível uma análise mais detalhada sobre os possíveis Direitos e interesses que podem ser objeto de tutela da Ação Civil Pública.

\section{Direitos ou interesses tuteláveis em Ação Civil Pública}

O Direito reflete a sociedade e a sociedade reflete o Direito. Com base nisso, as normas de Direito são instáveis e complexas, pois a cada mudança social também se altera a compreensão e a regulamentação dos Direitos. Apesar disso, o Direito se apresenta como esperança de segurança jurídica e locus inafastável para busca da justiça no Estado Democrático de Direito Contemporâneo.

A consagração ou positivação de Direitos Fundamentais passou por diversas etapas ao longo da história. Essas conquistas não se apresentam como camadas geológicas sedimentadas; senão como um caldo cultural borbulhante que lentamente percebe alterações essenciais. A classificação/evolução dos Direitos em gerações ou dimensão é bastante conhecida, bastando aqui a mera referência ao costumeiro enquadramento dos direito de primeira geração/dimensão como Direitos Liberais (liberdades públicas), os de segunda geração/dimensão como Direitos Sociais (Estado do Bem-Estar Social) e os de terceira geração/dimensão como síntese dos anteriores, ou seja, Direitos Sociais transindividuais ou metaindividuais (coletivos em sentido amplo). ${ }^{11}$

Especificamente, em relação aos Direitos de terceira dimensão, cujas áreas mais notáveis são: Direito do Consumidor e Direto Ambiental, surgem os Direitos ou interesses difusos, coletivos em sentido estrito ou Direitos Individuais Homogêneos.

Direitos e interesses são palavras utilizadas na maioria das vezes como sinônimas, porém, a categoria Direitos está nitidamente atrelada à concepção de Direitos Subjetivos. Interesse, por seu turno, surge no contexto da proteção de bens coletivos em sentido amplo, os quais, classicamente, além de estarem

ou à própria sociedade considerada em seu sentido amplo. (...) Já os Direitos Individuais Homogêneos são, simplesmente, Direitos Subjetivos Individuais. (...) Para fins de tutela jurisdicional coletiva não faz sentido, portanto, sua versão singular (um único Direito homogêneo), já que a marca homogeneidade supões, necessariamente, uma relação de referência com outros Direitos Individuais assemelhados. (...) Quando se fala, pois em 'defesa coletiva' ou em 'tutela coletiva' de Direitos Homogêneos, o que se está qualificando como coletivo não é o Direito Material tutelado, mas sim o modo de tutelá-lo, o instrumento de sua defesa" (Zavascki, 2006, p. 41-43 ).

11. Cf. obra de Norberto Bobbio (2004) denominada A era dos direitos que se tornou referência obrigatória sobre o assunto. 
na esfera privada, ainda como pré-Direitos, não seriam Direitos exigíveis subjetivamente, ou justicializáveis, de forma direta. De todo modo, as expressões são utilizadas indistintamente na Constituição brasileira e na legislação infraconstitucional, a nosso ver de forma correta, sendo dispensável qualquer diferenciação.

Os interesses e Direitos Difusos são dispersos, espalhados ou "fragmentados" (Cappelletti; Garth, 1988, p. 26). O Código de Defesa do Consumidor tratou de estabelecer um conceito operacional de Direitos Difusos em seu art. 81, parágrafo único, I:

"Art. 81. A defesa dos interesses e Direitos dos consumidores e das vítimas poderá ser exercida em juízo individualmente, ou a título coletivo.

Parágrafo único. A defesa coletiva será exercida quando se tratar de:

I - interesses ou Direitos Difusos, assim entendidos, para efeitos deste Código, os transindividuais, de natureza indivisível, de que sejam titulares pessoas indeterminadas e ligadas por circunstâncias de fato (...)."

As características dos Direitos e interesses difusos consistem na indeterminação do sujeito e na indivisibilidade do objeto (bem jurídico). Somente se fala em Direito Difuso quando de fato é difusa a titularidade subjetiva desses interesses tutelados, quer dizer, seus titulares são substancialmente anônimos, pois de certa forma não podem ser determinados (Dinamarco, 2001, p. 51-52).

Em suma, Direitos ou interesses difusos podem ser considerados como um conjunto de interesses individuais, cujo objeto é indivisível, compartilhados por pessoas indetermináveis, que se encontram unidas por circunstâncias de fato conexas (Mazzilli, 2007, p. 50).

Dinamarco (2001, p. 53) afirma, ainda, que nos Direitos Difusos o bem jurídico protegido (ou o objeto) é indivisível, porque quando se instaura uma ação, para a sua defesa não é possível proteger somente um indivíduo, sem que a tutela não atinja automaticamente os demais membros de determinada comunidade que se encontram na mesma situação.

Por Direito Difuso podem ser relacionados: a pretensão de um meio ambiente sadio e preservado para as presentes e futuras gerações (art. $225 \mathrm{da}$ $\mathrm{CF} / 1988$ ); o direito de respirar um ar puro; a defesa do erário; a defesa do direito de proteção dos mananciais hídricos, entre outros.

De outra forma, os interesses coletivos são os transindividuais de natureza indivisível de que seja titular grupo, categoria ou classe de pessoas ligadas entre si ou com a parte contrária por uma relação jurídica base, conforme definição dada também pelo art. 81, parágrafo único, II, in fine, do CDC.

A respeito dos Direitos Coletivos, pronunciou-se Dinarmarco (2001, p. 56, grifos do autor): 
"Quando a Ação Civil Pública em análise for ajuizada por uma associação ou sindicato, não raro haverá a proteção de pessoas não pertencentes ao quadro associativo do autor, tanto que a coisa julgada dar-se-á ultra partes limitadamente ao grupo, categoria ou classe (art. 103, II, do CDC). Ou seja, não precisa ser associado do ente-autor para gozar as vantagens trazidas pelas demandas por ele ajuizadas."

Além disso, o interesse coletivo, é a síntese dos interesses individuais e não mera soma, sendo necessário que haja uma alma coletiva.

Em outras palavras, Marinoni (2009, p. 299) explica que os Direitos Coletivos, também chamados de Direitos Coletivos stricto sensu, possuem como titular determinado grupo, categoria ou classe de pessoas que estão ligadas entre si ou com violador ou potencial violador do Direito, por uma relação jurídica base. Desse modo, os Direitos Coletivos admitem que haja identificação de um conjunto de pessoas ou um núcleo determinado de sujeitos identificados como titulares do interesse defendido.

São exemplos de Direitos Coletivos: (a) o Direitos dos alunos de determinada escola de terem o ensino de qualidade ofertada a todos; (b) o aumento ilegal das prestações de um consórcio. Depois de individualizada a ilegalidade, que na origem era comum, cada pessoa poderá individualizar o seu prejuízo, ocorrendo, então, a disponibilidade do Direito.

Apesar disso, os Direitos Coletivos devem ser analisados com cuidado, pois é fácil a sua confusão com os Direitos Individuais Homogêneos. Há casos em que a indivisibilidade está somente na causa de pedir da ação e não na tutela propriamente dita. Um exemplo é o aumento ilegal das prestações referentes a um consórcio, em que os consorciados podem pleitear pela condenação da ilegalidade, porém, o resultado efetivo do processo atinge somente aos consorciados de maneira individualizada. Nesse caso, é direito ou interesse individual homogêneo (Dinamarco, 2001, p. 57).

Por sua vez, os Direitos Individuais Homogêneos são definidos pelo CDC como aqueles decorrentes de uma origem comum (art. 81, parágrafo único, III, in fine, do CDC).

Pela redação original da Lei da Ação Civil Pública, a Ação Civil Pública não poderia ser utilizada na tutela dos interesses individuais homogêneos. Todavia, com a publicação do Código de Defesa do Consumidor, que nas suas disposições finais modificou o texto da Ação Civil Pública, ${ }^{12}$ ampliou-se o campo de atuação

12. Art. 110 do CDC que modificou o texto da Lei da Ação Civil Pública. "Acrescente-se o seguinte inciso IV ao art. $1 .^{\circ}$ da Lei 7.347/1985:

(...)

IV - a qualquer outro interesse difuso ou coletivo". 
para abarcar também os direitos individuais homogêneos. O conceito de Direitos Individuais Homogêneos é dado por Dinamarco da seguinte forma (2001, p. 60):

"Os interesses individuais homogêneos são divisíveis, passíveis de ser atribuídos individual e proporcionalmente a cada um dos indivíduos interessados (que são identificáveis), sendo essa sua grande diferença com os interesses difusos ou coletivos (esses sim indivisíveis). Como já dito, essa indivisibilidade é do objeto do pedido e não da causa de pedir."

Os Direitos Individuais Homogêneos "compreendem os integrantes determinados ou determináveis de grupo, categoria ou classe de pessoas que compartilhem prejuízos divisíveis, oriundos das mesmas circunstâncias de fato" (Siqueira JR., 2009, p. 453).

Em outros termos, os Direitos Individuais Homogêneos são verdadeiros interesses individuais, contudo, são circunstancialmente tratados de forma coletiva, tendo em vista maior efetividade da tutela jurisdicional, o interesse público e também o Princípio da Economia Processual.

São características dos Direitos Individuais Homogêneos: (a) a determinabilidade dos sujeitos; (b) a origem fática comum; (c) a dispensa da existência de uma relação jurídica-base anterior à lesão, podendo ser ocasionada no próprio ato lesivo; (d) atinja um número de pessoas que justifique a tutela coletiva como mais benéfica do que em relação à ação individual; e (e) a citação de todos os interessados por edital para que intervenham no processo como litisconsortes (art. 94 do CDC) (Dinamarco, 2001, p. 61).

São exemplos dos Direitos Individuais Homogêneos: (a) investidores em certa modalidade de aplicação financeira; (b) acidente ocorrido no meio ambiente do trabalho; (c) os compradores de uma determinada marca de carro em que o lote apresentou defeito de fabricação; (d) alimento que venha a gerar intoxicação em inúmeras pessoas.

Ademais, apesar dessa conceituação genérica sobre os Direitos ou interesses tutelados pela Ação Civil Pública a Lei da Ação Civil Pública tutelou alguns Direitos específicos que merecem um estudo mais aprofundado.

\subsection{Direitos Sociais tutelados pela Ação Civil Pública}

Com a edição ${ }^{13}$ da Lei da Ação Civil Pública o legislador relacionou alguns bens tutelados pela Ação Civil Pública. Contudo, o rol previsto no art. 1. ${ }^{\circ}$ é meramente exemplificativo, como será demonstrado neste item.

13. Em razão das evoluções do direito processual civil, Jefferson Carús Guedes (2006, p. 156) apresenta interessante proposta para o estudo autônomo de um direito processual 
Inicialmente, é preciso analisar o conteúdo do art. 1. ${ }^{\circ}$ da Lei 7.347/1985:

"Art. 1. ${ }^{\circ}$ Regem-se pelas disposições desta Lei, sem prejuízo da Ação Popular, as ações de responsabilidade por danos morais e patrimoniais causados:

I - ao meio ambiente;

II - ao consumidor;

III - a bens e direitos de valor artístico, estético, histórico, turístico e paisagístico;

IV - a qualquer outro interesse difuso ou coletivo;

V - por infração da ordem econômica e da economia popular;

VI - à ordem urbanística;

Parágrafo único. Não será cabível Ação Civil Pública para veicular pretensões que envolvam tributos, contribuições previdenciárias, o Fundo de Garantia de Tempo de Serviço - FGTS ou outros fundos de natureza institucional cujos beneficiários podem ser individualmente determinados."

Observe-se o enunciado do inc. IV do art. $1 .^{\circ}$ da Lei 7.347/1985, que amplia o rol dos Direitos e interesses tutelados pela Ação Civil Pública a qualquer outro interesse difuso ou coletivo, segundo redação dada pelo Código de Defesa do Consumidor.

Desta forma, pela simples leitura do dispositivo depreende-se que o rol estabelecido é meramente exemplificativo, pois há alguns Direitos tutelados pela Ação Civil Pública que não se encontram no rol previsto no art. $1 .^{\circ}$ da Lei 7.347/1985.

A proteção de interesses coletivos e difusos das pessoas portadores de deficiências é um desses Direitos tutelados pela legislação esparsa. Sua previsão está na Lei 7.853/1989, que dispõe sobre o apoio às pessoas portadoras de deficiências e sua integração social.

Nos arts. 3..$^{\circ}$ ao $7 .^{\circ}$ da referida lei estão relacionadas às peculiaridades do procedimento judicial da Ação Civil Pública quando se tutela interesses coletivos ou difusos das pessoas portadoras de deficiência. Além disso, há disposição expressa na Lei 7.853/1989 de que a Lei da Ação Civil Pública é utilizada subsidiariamente também nesse procedimento.

previdenciário e assistencial social: "O direito processual previdenciário e assistencial social pode ser descrito como o conjunto de princípios e regras processuais que regulam os procedimentos com vistas à aquisição dos benefícios previdenciários e assistenciais (...)". Ponderamos, com relação à proposta do autor, que devido à profusão de ações relativas à saúde, essa dimensão também possa ser incluída na proposta conceitual. 
Além disso, os interesses difusos e coletivos da criança e do adolescente também podem ser amparados pela Ação Civil Pública, consoante a Lei 8.069/1990, que define o Estatuto da Criança e do Adolescente (ECA).

$\mathrm{O}$ art. 3. ${ }^{\circ}$ do mesmo Estatuto define:

"Art. 3. A criança e o adolescente gozam de todos os Direitos Fundamentais inerentes à pessoa humana, sem prejuízo da proteção integral de que trata esta Lei, assegurando-se-lhes, por lei ou por outros meios, todas as oportunidades e facilidades, a fim de lhes facultar o desenvolvimento físico, mental, moral, espiritual e social, em condições de liberdade e de dignidade."

Destarte, no Capítulo VII do Estatuto da Criança e do Adolescente há disposição referente à proteção judicial dos interesses individuais, difusos e coletivos das crianças e adolescentes, ressaltando a proteção ao ensino obrigatório, ao atendimento educacional especializado aos portadores de deficiência, ao atendimento em creche e pré-escola às crianças de zero a seis anos de idade; ensino noturno regular; acesso às ações e serviços de saúde, a escolarização e profissionalização dos adolescentes privados de liberdade (art. 208 da Lei 8.069/1990).

O ECA, ainda, determina no art. 224 que se aplicam subsidiariamente, no que couberem, as disposições da Lei da Ação Civil Pública. Assim, a Ação Civil Pública é o instrumento adequado na tutela de Direitos Difusos e Coletivos e Individuais Homogêneos quando se refere à proteção das crianças e adolescentes.

Também, constitui função do Ministério Público defender judicialmente os Direitos e interesses das populações indígenas (art. 129, V, da CF/1988). A LC 75/1993, que define a Lei Orgânica do Ministério Público da União - Lompu, prevê no art. $6^{\circ}$, VII, $c$, a proteção dos interesses individuais indisponíveis, difusos e coletivos, relativos às comunidades indígenas e às minorias étnicas.

Embora, a defesa das minorias étnicas não esteja arrolada como uma das funções institucionais do Ministério Público pode ser enquadrada na expressão "(...) outros interesses difusos e coletivos" (art. 129, III, in fine, da CF/1988), portanto, cabe a esse órgão proteger também esses Direitos.

Assim, sempre que houver violação a interesse ou direito indígena e das minorias pode ser proposta uma Ação Civil Pública para proteger esse Direito e punir os responsáveis pelos danos causados a tais indivíduos.

A moralidade administrativa também pode ser objeto de tutela da Ação Civil Pública, pois o que se busca proteger é a boa administração, segundo as normas legais e aos princípios constitucionais previstos nos art. 37 e ss. da CF/1988. 
Além disso, a Lei 8.625/1993 indica:

"Art. 25. Além das funções previstas nas Constituições Federal e Estadual, na Lei Orgânica e em outras leis, incumbe, ainda, ao Ministério Público:

(...)

IV - promover o inquérito civil e a ação civil pública, na forma da lei:

(...)

b) para a anulação ou declaração de nulidade de atos lesivos ao patrimônio público ou à moralidade administrativa do Estado ou de Município, de suas administrações indiretas ou fundacionais ou de entidades privadas de que participem."

Assim, na tutela da moralidade administrativa é preciso verificar-se se o administrador está respeitando os princípios insculpidos na CF/1988 (art. 37, caput), além das disposições da Lei 8.429/1992, conhecida como Lei da Improbidade Administrativa (LIA). Portanto, se o administrador age dentro dos limites da honestidade, imparcialidade e da lealdade ao gerir os recursos de toda a coletividade pode-se afirmar que está agindo de acordo com a moralidade administrativa. (MAzzilli, 2007, p. 185).

Acrescenta-se a aqui uma possibilidade ainda olvidada de utilização da LIA. Ao sindicarem-se $\mathrm{s}^{14}$ os atos administrativos seja pela via fiscalizatória dos legislativos (com a colaboração dos Tribunais de Contas), seja ainda pelos controles: interno, judicial ou social, os atos administrativos dolosos, tendentes à violação ou violadores dos direitos sociais poderão ser punidos.

Com efeito, se o administrando pratica qualquer ato que importe em improbidade administrativa (arts. 9. ${ }^{\circ}$ a 11 da Lei 8.429/1992) o Ministério Público poderá valer-se da Ação Civil Pública para investigar tais atos, pois atua na defesa dos interesses indisponíveis da sociedade.

Enfim, a Lei 12.288/2010, que institui o Estatuto da Igualdade Racial, no art. 55 dispõe:

"Art. 55. Para a apreciação judicial das lesões e das ameaças de lesão aos interesses da população negra decorrentes de situações de desigualdade étnica, recorrer-se-á, entre outros instrumentos, à ação civil pública, disciplinada na Lei n. 7.347, de 24 de julho de 1985."

Por conseguinte, sempre que uma lesão ou ameaça estiver verificada em face da população negra decorrente em virtude de desigualdade ética, o instrumento jurídico à sua proteção é a Ação Civil Pública.

14. Freitas, Juarez. O controle dos atos administrativos e os princípios fundamentais. 4. ed. São Paulo: Malheiros, 2009. 
Como frisado, a Ação Civil Pública tutela quaisquer Direitos Difusos ou Coletivos (art. 1. ${ }^{\circ}$, IV, da Lei 7.347/1985). Nesse esteio, a defesa ao Direito de Moradia também pode se enquadrar como um Direito Difuso ou Coletivo.

Nesse sentido, posicionou-se o STJ em decisão no RE 1.013.153/RS, julgado pelo Min. Herman Benjamin, em 28.10.2008, ao afirmar que no Direito Urbanístico, sobretudo quando trata da garantia do Direito à Moradia Digna, afloraram, simultânea e inseparavelmente, Direitos e interesses individuais homogêneos (em relação aos sem-teto, moradores de favelas...) e outros de índole difusa (quando diz respeito à coletividade, que também é negativamente afetada, nos planos ético e material da qualidade de vida). Ademais, a retirada de casas em situação irregular com o consequente remanejamento das famílias em área digna à moradia, representa benefício de natureza difusa, em prol da sociedade como um todo.

Infere-se, pelo exposto, que o rol previsto no art. 1. ${ }^{\circ}$ da Lei 7.347/1985 é meramente exemplificativo, uma vez que é possível por meio da Ação Civil Pública defender quaisquer Direitos e interesses difusos, coletivos e individuais homogêneos.

Não se deve restringir (como de fato não se restringe) o campo de atuação da Ação Civil Pública, pois é utilizada pelos seus legitimados ativos no intuito de defender igualitariamente os Direitos de determinado grupo, seja de pessoas determináveis ou indetermináveis.

Igualmente, a Ação Civil Pública tem sido utilizada com a finalidade de racionalizar a utilização do Poder Judiciário, pois a partir do momento em que se tutela Direitos Difusos, Coletivos ou Individuais Homogêneos por meio de uma única demanda, evita-se que várias outras ações individuais sejam propostas. Logo, quanto mais ampla a tutela da Ação Civil Pública, mais eficaz poderá ser a proteção dos Direitos tutelados.

Ainda, é preciso analisar quem possui legitimidade para ingressar com a Ação Civil Pública, uma vez que somente determinadas instituições possuem competência para a propositura de tal demanda.

\subsection{Legitimados ativos da Ação Civil Pública}

A legitimidade ativa da Ação Civil Pública vem insculpida no art. 5. ${ }^{\circ}$ da Lei 7.347/1985, alterado pela Lei 11.448/2007:

"Art. 5. ${ }^{\circ}$ Têm legitimidade para propor a ação principal e a ação cautelar:

I - o Ministério Público;

II - a Defensoria Pública; 
III - a União, os Estados, o Distrito Federal e os Municípios;

IV - a autarquia, empresa pública, fundação ou sociedade de economia mista;

$\mathrm{V}$ - a associação que, concomitantemente:

a) esteja constituída há pelo menos 1 (um) ano nos termos da lei civil;

b) inclua, entre suas finalidades institucionais, a proteção ao meio ambiente, ao consumidor, à ordem econômica, à livre concorrência ou ao patrimônio artístico, estético, histórico, turístico e paisagístico (...).”

No entanto, outras leis também estabelecem a legitimidade ativa da Ação Civil Pública: O Código de Defesa do Consumidor, no art. 82, enumera os mesmos colegitimados, acrescentando os órgãos ou entidades sem personalidade jurídica. A Lei 7.853/1989 ${ }^{15}$ outorga praticamente os mesmos legitimados da Lei de Ação Civil Pública, mas as entidades devem incluir entre suas finalidades a proteção a pessoas portadoras de deficiências (art. 3. $^{\circ}$ ). O ECA, no art. 20, trata dos colegitimados para a defesa da criança e do adolescente, não mencionando as autarquias, empresas públicas, fundações e sociedades de economia mista.

Contudo, a legitimidade ativa de uma instituição não exclui as demais, porque quando se trata de Ação Civil Pública, a legitimidade é concorrente e disjuntiva. Concorrente porque os legitimados ativos (art. 5. ${ }^{\circ}$ da Lei 7.347/1985 e art. 82 do CDC) podem agir em defesa de interesses transindividuais. É disjuntiva porque os colegitimados não precisam comparecer em litisconsórcio. Portando, os colegitimados podem atuar judicialmente em litisconsórcio ou isoladamente. (Mazzilli, 2007, p. 314).

A Constituição de 1988 deixou cristalina essa possibilidade quando estabeleceu que a legitimação do Ministério Público para a Ação Civil Pública não impede a dos demais legitimados, nas mesmas hipóteses (art. 129, § 1. ${ }^{\circ}$, da CF/1988).

MAzzilli (2007, p. 290) assevera que a pertinência temática é um requisito imprescindível à propositura da Ação Civil Pública, e corresponde à finalidade institucional compatível com a defesa judicial do interesse.

Já a representatividade adequada significa que determinados colegitimados (associações e sindicatos, por exemplo) podem estabelecer em seus estatutos

15. Que dispõe sobre o apoio às pessoas portadoras de deficiência, sua integração social, sobre a Coordenadoria Nacional para Integração da Pessoa Portadora de Deficiência (Corde), institui a tutela jurisdicional de interesses coletivos ou difusos dessas pessoas, disciplina a atuação do Ministério Público, define crimes, e dá outras providências. 
finalidades secundárias que guardem relação com outros direitos difusos e coletivos, podendo tutelar direitos além daqueles da área primária de atuação. No entanto, devem demonstrar a correlação entre a finalidade da entidade e o objeto da demanda. (Siqueira JR., 2009, p. 436).

É indispensável analisar cada caso concreto para verificar o interesse de agir do colegitimado da Ação Civil Pública, pois a ofensa do bem tutelado deve relacionar-se, direta ou indiretamente, com o objeto jurídico do legitimado atuante em juízo. (Siqueira Jr., 2009, p. 439).

O Ministério Público possui legitimação ativa para propor a Ação Civil Pública desde 1985, com a edição da Lei da Ação Civil Pública, em face dos interesses ou Direitos Difusos ou Coletivos. Com a edição do CDC, em 1990, também os Direitos Individuais Homogêneos passaram a ser tutelados pelo Ministério Público (arts. 91 a 100 do CDC).

Por meio da Ação Civil Pública, o Ministério Público pode em nome próprio e no interesse das vítimas ajuizarem uma única demanda que poderá beneficiar todos os lesados, resultando numa solução mais rápida do conflito e em sensível economia de tempo e dinheiro (Almeida, 2001, p. 97).

Todavia, a intervenção ministerial é limitada levando-se em consideração o interesse a ser tutelado. Sobre isso, é fundamental esclarecer que os interesses podem ser disponíveis, indisponíveis ou de disponibilidade restrita, independentemente de quem seja seu titular (Mazzilli, 2007, p. 93).

Para restringir a disponibilidade de um interesse é necessária uma norma de ordem pública, sob o aspecto objetivo, unicamente. Há casos em que a indisponibilidade liga-se à defesa de um dos titulares da relação jurídica, não tendo conexão com a natureza jurídica, um exemplo, é o interesse do incapaz (Mazzilli, 2007, p. 93).

Desse modo, Mazzilli (2007, p. 83) assevera que a indisponibilidade do interesse pode ser total ou parcial. A indisponibilidade total (ou absoluta) significa a impossibilidade de que o Direito seja objeto de abdicação total ou parcial ou de transação. Contudo, há interesses que são indisponíveis, que em parte permitem transação, permitindo ao Ministério Público fiscalizar essa indisponibilidade parcial, como nos casos de guarda de filhos, alimentos, entre outros.

A indisponibilidade não esgota a possibilidades de intervenção ministerial, pois mesmo que há interesses disponíveis, poderá atuar o órgão ministerial desde que sua defesa convenha à coletividade (Mazzilli, 2007, p. 94).

Sendo assim, a intervenção ministerial na tutela de um interesse difuso é sempre cabível, em vista de sua larga abrangência. Diferente do que ocorre na tutela de interesses coletivos ou individuais homogêneos, em que o órgão mi- 
nisterial somente atuará quando: "(a) haja manifesto interesse social evidenciado pela dimensão ou pelas características do dano, ainda que potencial, (b) seja acentuada a relevância social do bem jurídico a ser defendido; (c) esteja em questão a estabilidade de um sistema social jurídico ou econômico, cuja preservação aproveite a toda a coletividade" (MAzzilli, 2007, p. 170).

Segundo a opinião de Siqueira Jr. (2009, p. 453), "A Ação Civil Pública só terá por objeto interesses individuais homogêneos desde que presente o interesse público ou relevância social (...)".

A Ação Civil Pública deve ser utilizada como um instrumento de tutela dos interesses individuais homogêneos socialmente relevantes, não se prestando à tutela de Direitos Individuais Subjetivos, cujos titulares, quando dispuserem de amplas condições sociais e culturais de acesso ao judiciário deverão socorrer-se das vias ordinárias para pleitear os seus interesses.

Se a defesa de um direito/interesse coletivo ou individual homogêneo convier à coletividade como um todo deve o Ministério Público atuar na sua tutela. Mas, o Parquet não atua na tutela de interesses de pequenos grupos, sem características de indisponibilidade ou sem suficiente abrangência social (Mazzilli, 2007, p. 170).

Outros detalhes ${ }^{16}$ ainda poderiam ser desenvolvidos aqui, no concernente às peculiaridades dogmáticas quanto aos entes legitimados para a propositura da Ação Civil Pública. Todavia, por questão de recorte metodológico, o presente texto passa a analisar alguns precedentes tendentes a praticar uma interpretação evolutiva ${ }^{17}$ sobre a matéria.

16. Ives Gandra da Silva Martins (1994) publicou parecer concedido à Prefeitura de Lençois Paulista, no qual advoga a inadequação de Ação Civil Pública contra a cobrança de IPTU, considerando a matéria de direito individual disponível. No mesmo sentido, conferir: STF, RE 195056/PR, Pleno, j. 09.12.1999, rel. Min. Carlos Velloso, DJ 14.11.2003.

17. "Uma interpretação evolutiva dos Direitos Fundamentais Sociais deve se interessar pelos Direitos que são acrescidos ao sistema, e por via judicial. Seu objeto deve ser a inovação por adição judicial. Essa teoria deve identificar e compreender os fundamentos das respostas aditivas dadas pelo sistema judicial às expectativas normativas vigentes. Isso significa que deve se dedicar a sistematizar os Direitos Fundamentais Sociais vigentes e a investigar os parâmetros adotados pelos tribunais para promover adições de tipo, de sentido e de alcance. E isso porque as interpretações evolutivas de Direitos Fundamentais Sociais podem afetar os Direitos Materiais ou os Direitos Processuais (de ação, procedimentais, de partes e de tutela jurisdicional" (STRAPAzzon, 2010, p. 230). 


\section{Precedentes em matéria de Ação Civil Pública para a proteção de Direitos Sociais Individuais Homogêneos}

A eficácia jurídica dos Direitos Fundamentais Sociais é invariavelmente motivo para ilações e ambiguidades dogmáticas, jurisprudenciais e ideológicas. Saber se determinado Direito Social pode ser reivindicado judicialmente e em que medida o judiciário pode determinar que os demais poderes estatais promovam esses Direitos é questão crucial no funcionamento do constitucionalismo contemporâneo. ${ }^{18}$

Quando se trata de interesses difusos não há dúvidas quanto ao cabimento da ACP. Quanto aos Direitos Coletivos e Individuais Homogêneos é imprescindível que o objeto tutelado transcenda a noção do indivíduo, pois se a matéria versar unicamente sobre interesses disponíveis, e sem relevância social, o meio adequado é uma ação ordinária proposta pelo particular, seu legitimado ativo.

Portanto, o Ministério Público possui legitimidade ativa na tutela de interesses/Direitos Coletivos e Individuais Homogêneos somente quando há relevância social e/ou Direito Indisponível, bem como os demais legitimados, desde que atendidas as peculiaridades de cada caso. ${ }^{19}$

Interessante perceber-se que a expressão "relevância social" é de notável abertura semântica e vagueza, não comportando qualquer conceituação excessivamente fechada. Nesse aspecto, não se correria o risco de termos uma inclinação jurisprudencial destoante das legítimas aspirações sociais (luta por novos Direitos) e dos princípios consagrados no texto constitucional? Como garantir-se, então, que as decisões proferidas nas Ações Civis Públicas sejam racionais e garantam a eficácia dos enunciados normativos legislados para a proteção dos interesses individuais homogêneos?

Em Alexy (2008, p. 550) encontramos a defesa de que é possível seguir-se um caminho argumentativo racional, sendo imprescindível na solução dos conflitos jurídicos uma construção argumentativa que apresente justificação suficiente que permita o controle racional da decisão. O autor propõe um modelo procedimental em quatro níveis.

18. Apenas para fazer um contraponto, os autores Ricardo Lobo Torres (2009) e Cass R. Susnstein (2009) defendem que os Direitos Sociais não são Direitos Fundamentais, somente os Individuais.

19. Conferir artigo de José Maria Rosa Tesheiner e Mariângela Guerreiro Milhoranza (2009), no qual os autores propõem que se não deve utilizar o critério da disponibilidade para sonegar direitos previdenciários (individuais homogêneos) postulados por meio de ações coletivas. 
No primeiro nível está o discurso prático geral - as razões gerais, através das quais de forma alguma se poderiam chegar a uma única solução para cada caso. No segundo nível está o processo legislativo, que oferece um sistema de regras importantes, mas que, "como demonstram experiências históricas quanto reflexões conceituais", não determina, de antemão, uma solução para cada caso. No terceiro nível está o discurso jurídico, cuja vinculação à lei, ao precedente e à dogmática reduz consideravelmente a incerteza com relação ao discurso prático geral, porém, ainda não é capaz de apresentar uma solução única. Por fim, o quarto procedimento (institucionalizado) é o processo judicial "no qual, da mesma forma que ocorre no processo legislativo, não apenas se argumenta, mas também se decide". Haverá, então, racionalidade, se, no processo judicial decisório houver respeito aos três primeiros modelos de discurso (Alexy, 2008, p. 550).

O fato de as questões valorativas deixadas em aberto pelo material normativo existente serem, no processo judicial, objeto não apenas de argumentação, mas também de decisão, não implica uma renúncia à racionalidade. Em primeiro lugar, porque essas questões, valorativas são decididas a partir de vinculações que, enquanto tais, e como demonstra o modelo, são racionais; em segundo lugar, porque essas questões valorativas podem ser decididas com base em uma argumentação prática racional, o que confere à decisão um caráter racional mesmo que mais de uma decisão seja possível nos termos das regras da argumentação prática racional.

Existem ainda muitas outras teorias argumentativas, métodos e procedimentos para obter-se racionalidade na decisão de casos jurídicos. ${ }^{20} \mathrm{~A}$ virada linguística é importante prisma para notar-se que a fundamentação dos discursos ocorre previamente, na pré-compreensão do sujeito e, que, o saber é sempre intersubjetivo. Na expressão de Gadamer (2007), o intérprete deve livrar-se dos seus pré-conceitos ruins e assumir os bons pré-conceitos sempre

20. Maccormick, Neil. Argumentação jurídica e teoria do Direito. São Paulo: Martins Fontes, 2006. Perlman, Chaim \& Olbrechts-Tyteca, Lucil. Tratado de argumentação: a nova retórica. São Paulo: Martins Fontes, 1996. Tulmin, Stephen. Os usos do argumento. 2. ed. São Paulo: Martins Fontes, 2006. Juarez Freitas sustenta que "bem pensada, a interpretação jurídica é interpretação sistemática ou não é interpretação. Nessa ordem de ideias, a interpretação sistemática deve ser concebida como uma operação que consiste em atribuir, topicamente, a melhor significação, dentre várias possíveis, aos princípios, às normas estritas (ou regras) e aos valores jurídicos, hierarquizando-os num todo aberto, fixando-lhes o alcance e superando as antinomias em sentido amplo, tendo em vista bem solucionar os casos sob apreciação" (Freitas, 2010, p. 276). 
ao concretizar seus projetos hermenêuticos. Com efeito, na iniciativa do hermeneuta em explicitar razões, tomando uma posição quanto ao que está sendo posto em causa, surge a especial relevância e inter-relação inafastável entre a compreensão e o discurso, entre a hermenêutica e a argumentação.

Quanto à possibilidade de tutela dos Direitos Individuais Homogêneos em sede de Ação Civil Pública, deve-se notar a considerável evolução jurisprudencial evidenciada pelos tribunais superiores brasileiros.

Veja-se que, de início, no processo legislativo da Lei da Ação Civil Pública em 1985, houve veto presidencial ao inc. IV do art. $1 .^{\circ}$, cuja redação ampliava as hipóteses de cabimento de Ação Civil Pública para "qualquer outro interesse difuso ou coletivo". ${ }^{21}$ Já em 1990, o Código de Defesa do Consumidor fez previsão expressa dos Direitos Individuais Homogêneos (art. 81, IIII) e, nas disposições, o art. 110 do CDC, incluiu o inc. IV no art. 1. ${ }^{\circ}$ da Lei 7.347/1985, na mesma redação da proposta inicial. Então, em 1985 a expressão foi considerada muito abrangente. A experiência jurídica demonstrava inconveniente por razões de segurança jurídica. No ano 2000 esse motivo já não foi mais relevado no processo legislativo.

Nesse passo ampliativo e evolutivo das causa em que a Ação Civil Pública pode ser manejada na defesa e proteção dos Direitos Individuais Homogêneos

21. As razões do veto foram as seguintes:

“(...) As razões de interesse público dizem respeito precipuamente a insegurança jurídica, em detrimento do bem comum, que decorre da amplíssima e imprecisa abrangência da expressão 'qualquer outro interesse difuso'.

A amplitude de que se revestem as expressões ora vetadas do projeto mostra-se, no presente momento de nossa experiência jurídica, inconveniente.

É preciso que a questão dos interesses difusos, de inegável relevância social, mereça, ainda, maior reflexão e análise. Trata-se de instituto cujos pressupostos conceituais derivam de um processo de elaboração doutrinária, a recomendar, com a publicação desta Lei, discussão abrangente em todas as esferas de nossa vida social.

É importante, neste momento, que, em relação à defesa e preservação dos direitos dos consumidores, assim como do patrimônio ecológico, natural e cultural do País, a tutela jurisdicional dos interesses difusos deixe de ser uma questão meramente acadêmica para converter-se em realidade jurídico-positiva, de verdadeiro alcance e conteúdo sociais.

Eventuais hipóteses rebeldes à previsão do legislador, mas ditadas pela complexidade da vida social, merecerão a oportuna disciplinação legislativa.

Estas as razões de interesse público que me levaram ao veto parcial e que ora tenho a honra de submeter à elevada apreciação dos Senhores Membros do Congresso Nacional" (Mensagem 359/1985. Disponível em: [www.planalto.gov.br/ccivil_03/leis/ Mensagem_Veto/anterior_98/Mvep359-85.htm]. Acesso em: 28.04.2011). 
ligados direta ou indiretamente à Seguridade Social, tem ainda alguns precedentes que merecem colação. Antes disso, merece referência a constatação de Victor Abramovich e Christian Courtis (2004, p. 223). Para os autores o contexto brasileiro mostra exemplos interessantíssimos de como a combinação da legislação de proteção ao consumidor com as formas processuais de representação dos Direitos Transindividuais têm redundado na tutela de Direitos Sociais com saúde, educação e moradia.

Os autores ressaltam a importância Ações Civis Públicas ajuizadas pelo Ministério Público para os contratantes de plano de saúde, pais de crianças que estudam em escolas privadas, contratantes de planos de habitação (correção abusiva das prestações), dentre outros casos (Aвramovich; Courtis, 2004, p. 224).

Com efeito, para que o presente texto tenha alguma utilizada prática, não basta a análise das pretensões constantes dos pedidos nas referidas ações civis públicas. Interessa, sobremodo, a causa de pedir, pois, como já dito neste trabalho, a diferença entre um Direito Difuso e um Individual Homogêneo muitas vezes residirá na causa de pedir. Deve-se ressaltar que, de qualquer sorte, independentemente do "enquadramento" que se dê a determinado interesse ou Direito, o processo para a tutela de Direitos Coletivos empreendeu significativos avanços desde a Constituição de 1988.

Alguns julgados, então, podem ser úteis para a aplicação da matéria. Seguem abaixo três precedentes do STJ. Um na área da saúde, outro da previdência e outro da assistência social.

No REsp 413.986/PR (5. ${ }^{a}$ T., j. 15.10.2002, rel. Min. José Arnaldo da Fonseca, DJ 11.11.2002) o Instituto Nacional do Seguro Social recorreu ao STJ alegando que o Ministério Público não detinha legitimidade para questionar uma exigência administrativa segundo a qual somente seriam aceitos como início de prova documental, para a comprovação de atividade de produtor rural em regime de economia familiar, documentos que fizessem referência direta ao nome do interessado. No recurso, o INSS afirmou que os direitos previdenciários não são suscetíveis de tutela mediante Ação Civil Pública, por serem individuais homogêneos não caracterizados como relação de consumo. A tese da autarquia foi refutada pelo STJ, constando da ementa:

"Recurso especial. Previdenciário. Ação Civil Pública. Ministério Público Federal.

O Ministério Público está legitimado a defender Direitos Individuais Homogêneos, quando tais Direitos têm repercussão no interesse público.

O exercício das ações coletivas pelo Ministério Público deve ser admitido com largueza. Em verdade a ação coletiva, ao tempo em que propicia solução uniforme para todos os envolvidos no problema, livra o Poder Judiciário da maior praga que o aflige, a repetição de processos idênticos. 
Recurso conhecido, mas desprovido."

$\mathrm{Na}$ fundamentação do acórdão, constou negritada a seguinte citação de Ada Pellegrini Grinover, uma das coautoras do anteprojeto do Código de Defesa do Consumidor, deixando a impressão de que há uma tendência à um alargamento na compreensão dos direitos coletivos, especialmente os individuais homogêneos, sejam eles disponíveis ou não, desde que haja um interesse público:

"Assim, foi exatamente a relevância social da tutela coletiva dos interesses ou Direitos Individuais Homogêneos que levou o legislador ordinário a conferir ao Ministério Público e a outros entes públicos a legitimação para agir nessa modalidade de demanda, mesmo em se tratando de interesses ou Direitos disponíveis" (GRINOVER, 2004, p. 554).

Já no REsp 703.471/RN (2. ${ }^{a}$ T., j. 25.10.2005, rel. Min. João Otávio de Noronha, DJ 21.11.2005), o STJ foi instado a decidir em última instância uma Ação Civil Pública em que o Ministério Público objetivou a liberação de verbas destinadas ao combate do mosquito aedes aegypti, o pagamento de indenização às vítimas da dengue ou a seus sucessores e a realização de campanha informativa visando a prevenção e o combate a essa moléstia. Neste caso, o pedido do Ministério Público para que houvesse liberação de verba federal específica para o município foi julgada improcedente porque tal importância ainda não havia sido liberada por culpa do próprio município (falta de adesão ao programa federal). O Recurso Especial foi provido no que diz respeito também às indenizações a serem pagas às vítimas e seus sucessores, aduzindo que o estado não agiu com culpa, a qual, nesse caso deveria se considerada em sua modalidade subjetiva. E, o STJ considerou que, apesar de tratar-se de direito difuso, quando da liquidação das indenizações passar-se-ia a tratar-se de direitos individuais disponíveis, perdendo nesse aspecto, a legitimidade do Ministério Público. Quanto à campanha informativa, essa perdeu o objeto em razão do seu cumprimento no curso do processo. ${ }^{22}$

22. A decisão do TRF-3. ${ }^{a}$ Reg. era totalmente oposta:

"Apelações e remessa oficial. Ação Civil Pública. Dengue. Legitimidade do Ministério Público Federal ante o Direito à Saúde (art. 129, III, da CF). Responsabilidade estatal caracterizada pela faute de service. Improvimento.

I - O Constituinte de 1988, em sintonia com o evolver dos Direitos Fundamentais de terceira geração, conferiu, no art. 129, III, de sua obra, legitimidade ao Ministério Público para a tutela judicial dos interesses difusos e coletivos, entre os quais está o Direito à Saúde, o qual pertence à coletividade como um todo (art. 196, caput).

II - A responsabilidade estatal em decorrência de omissão no atuar administrativo se baliza pela Teoria da Culpa Administrativa, a qual, sem embargo de respeitáveis opiniões em contrário, é de caráter objetivo, reportando-se à prestação insatisfatória do serviço público. 
Ainda no aspecto do Direito à Saúde há diversos precedentes do STJ, ora tratando o Direito à Saúde como Direito Individual Indisponível (STJ, REsp 948.579/RS, 1. ${ }^{a}$ T., j. 28.08.2007, rel. Min. José Delgado, DJ 13.09.2007), ${ }^{23}$ quando se trata de fornecimento de medicamento a uma pessoa, por exemplo, ora como Direito Individual Homogêneo, quando, v.g., algum órgão estatal não está dispensando medicamentos em quantia suficiente. No AgRg 1.247.323 (2. ${ }^{a}$ T., j. 08.06.2010, rel. Min. Herman Benjamin, DJe 30.06.2010), constou a seguinte lição:

"No que tange à alegação de ilegitimidade do Ministério Público Federal para ajuizar Ação Civil Pública, com o objetivo de obrigar a União a fornecer regularmente medicamentos ao Município, também não merece prosperar. Em se tratando de defesa a Direito Individual Homogêneo, como é o caso do Direito à Saúde, consubstanciado no Direito ao Acesso a Medicamentos, o Ministério Público está legitimado para ajuizamento de Ação Civil Pública (art. 129, III, da CF/1988) pelo art. 82, I, do CDC e do art. $6 .^{\circ}$, XII, da LC 75/1993..$^{24}$

III - A ausência de ação administrativa eficiente no combate à dengue, a resultar na vertiginosa proliferação da doença, situação previsível ante a notória notícia do retorno daquela ao território nacional há onze anos antes dos fatos que originaram a demanda, caracteriza o mau funcionamento do serviço público de saúde, cuja prestação é atributo dos demandados (art. 198, §§ 1. ${ }^{\circ}$ e $2 .^{\circ}$, da CF/1988), implicando na responsabilidade do Poder Público na forma do art. $37, \S 66^{\circ}$, da Lei Máxima.

IV - Apelações e remessa oficial improvidas."

23. O Min. Teori Albino Zavaski tem firmado entendimento de que o direito à saúde e a vida são direitos indisponíveis (STJ, EREsp 819.010/SP, 1. Seção, j. 13.02.2008, rel. p/ acórdão Min. Teori Albino Zavascki, DJ 29.09.2008): "Tem natureza de interesse indisponível a tutela jurisdicional do Direito à Vida e à Saúde de que tratam os arts. 5..$^{\circ}$, caput e 196 da CF/1988, em favor de menor carente que necessita de medicamento. A legitimidade ativa, portanto, se afirma, não por se tratar de tutela de Direitos Individuais Homogêneos, mas sim por se tratar de interesses individuais indisponíveis. Precedentes: STJ, EREsp 734.493/RS, 1. ${ }^{a}$ Seção, j. 27.09.2006, rel. Min. Castro Meira, DJ 16.10.2006; STJ, REsp 826.641/RS, 1. ${ }^{a}$ T., j. 20.06.2006, de minha relatoria, DJ 30.06.2006; REsp 716.512/RS, 1. ${ }^{a}$ T., j. 03.11.2005, rel. Min. Luiz Fux, DJ 14.11.2005; STJ, EDcl no REsp 662.033/RS, 1. ${ }^{a}$ T., j. 19.04.2005, rel. Min. José Delgado, DJ 13.06.2005; STJ, REsp 856.194/RS, 2. ${ }^{a}$ T., j. 12.09.2006, rel. Min. Humberto Martins, DJ 22.09.2006; STJ, REsp 688.052/RS, 2. ${ }^{a}$ T., j. 03.08.2006, rel. Min. Humberto Martins, DJ 17.08.2006. Verifica-se que os precedentes citados tratam de ações para fornecimento específico de medicamentos.

24. Para melhor compreensão dos fatos, vale colacionar-se o seguinte trecho do acórdão: "Em sentido contrário ao que alega a União Federal, os documentos colacionados às f. e ss. e os depoimentos colhidos na fase de instrução processual demonstram que há irregularidades no fornecimento de medicamentos pela União, ou seja, o ente estatal 
No AgRg em EDcl no REsp 1.075.839/MG (2.. T., j. 04.05.2010, rel. Min. Mauro Campbell Marques, DJe 27.05.2010) entendeu que o fornecimento de medicamentos é viável por meio de Ação Civil Pública ajuizada pelo Ministério Público. Porém, seu fundamento consistiu, em última instância, no Direito à Vida de menor carente.

No campo da assistência social, as Ações Civis Públicas não têm prosperado no STJ até o momento, encontrando séria resistência quanto à possibilidade de reconhecimento do Direito à Assistência Social (art. 203 da CF/1988), especialmente no que diz respeito ao direito a um salário mínimo ao portador de deficiência ou ao idoso carente. Ainda não há precedente no STJ admitindo Ação Civil Pública nesses casos, o que causa estranheza, pois, é justamente nos casos de benefícios assistenciais que a atuação por meio de substituição processual seria mais necessária. Os precedentes do STJ seguem a seguinte linha:

"Recurso Especial. Ação Civil Pública. Previdenciário. Ilegitimidade do Ministério Público. Assistência social. Portador de deficiência. Benefício de prestação continuada. Renda familiar.

O Ministério Público não tem legitimidade para ajuizar Ação Civil Pública relativa a benefício previdenciário, uma vez que se trata de interesse individual disponível.

Notadamente, o Texto Constitucional de 1988 dá uma dimensão sem precedentes ao Ministério Público, entretanto, convenço-me também de sua ilegitimidade para propor Ação Civil Pública nas hipóteses de benefícios previdenciários, uma vez que, a bem da verdade, trata-se de Direitos Individuais disponíveis que podem ser renunciados por seu titular e porque não se enquadram na hipótese de relação de consumo, uma vez que consumidor é toda pessoa física ou jurídica que adquire ou utiliza produto ou serviço como destinatário final, em que não se amolda a situação aqui enfrentada" (STJ, REsp 502.744/ SC (2003/0024431-2), 5. ${ }^{\text {T }}$ T., j. 12.04.2005, rel. Min. José Arnaldo da Fonseca, DJ 25.04.2005)..$^{25}$

não vem cumprindo a Portaria 371/2002 do Ministério da Saúde, dispensando medicamentos em quantia insuficiente, o que deixa clara a inexistência de perda de objeto e de falta interesse de agir".

25. O mais recente precedente nesse sentido é o seguinte: STJ, AgRg no REsp 1.030.065/ PI, (2007/0203013-7), 6. ${ }^{\text {T }}$., j. 07.10.2010, rel. Min. Celso Limongi (Desembargador Convocado do TJSP), DJ 25.10.2010. Em mesmo sentido: STJ, REsp 750.443/PR, 5. ${ }^{\text {a }}$ T., j. 19.03.2009, rel. Min. Arnaldo Esteves Lima, DJe 13.04.2009; AgRg no REsp 980.899/SP, 5. ${ }^{a}$ T., j. 26.08.2008, rel. Min. Jorge Mussi, DJe 28.10.2008; STJ, EREsp 448.684/RS, 3. ${ }^{a}$ Seção, j. 28.06.2006, rel. Min. Laurita Vaz, DJ 02.08.2006; STJ, REsp 
Os TRFs vêm admitindo Ação Civil Pública também para benefícios assistenciais, com base na jurisprudência do STJ, a qual, como se verá adiante assenta que tal meio processual é sempre legítimo para a tutela de interesses individuais homogêneos em que haja relevante interesse social. ${ }^{26}$

Ainda no que diz respeito à jurisprudência do STJ, vale assinalar mudança de entendimento recente, em acórdão relatado pela Min. Laurita Vaz. A Ministra, na linha do STJ vinha decidindo incabível a utilização de Ação Civil Pública para a revisão de benefícios previdenciários (v.g. STJ, EDiv em REsp 448.684/RS, 3. ${ }^{a}$ Seção, j. 28.06.2006, rel. Min. Laurita Vaz, DJ 02.08.2006). Porém, em recente decisão, ficou assentado entendimento totalmente diverso:

"Processual Civil e Previdenciário. Recurso especial. Ação Civil Pública destinada à tutela de Direitos de natureza previdenciária (no caso, revisão de benefícios). Existência de relevante interesse social. Legitimidade ativa ad causam do Ministério Público. Reconhecimento.

1. Para fins de tutela jurisdicional coletiva, os interesses individuais homogêneos classificam-se como subespécies dos interesses coletivos, previstos no art. 129, III, da CF/1988. Precedentes do STF. Por sua vez, a LC 75/1993 (art. 6. ${ }^{\circ}$, VII, a) e a Lei 8.625/1993 (art. 25, IV, a) legitimam o Ministério Público à propositura de Ação Civil Pública para a defesa de interesses individuais homogêneos, sociais e coletivos. Não subsiste, portanto, a alegação de falta de legitimidade do Parquet para a Ação Civil Pública pertinente à tutela de Direitos

502.744/SC, 5. ${ }^{\text {a }}$ T., j. 12.04.2005, rel. Min. José Arnaldo da Fonseca, DJ 25.04.2005; STJ AgRg no REsp 1.009.845/RS, 4. ${ }^{a}$ T., j. 04.06.2009, rel. Min. João Otávio de Noronha, DJE 15.06.2009; STJ, REsp 770.741/PA, 5. ${ }^{\mathrm{a}} \mathrm{T}$, j. 20.04.2006, rel. Min. Gilson Dipp, DJ 15.05.2006; STJ, REsp 700.098/SP, 5. ${ }^{a}$ T., j. 22.03.2005, rel. Min. Laurita Vaz, DJ 02.05.2005.

26. "Ementa: Previdenciário. Ação Civil Pública. Benefício assistencial. Ministério Público Federal. Legitimidade. Renda familiar per capita. Art. 34 do Estatuto do Idoso (Lei 10.741/2003). (...) 2. Consoante iterativa jurisprudência do STF, ao Ministério Público é dado promover, via ação coletiva, a defesa de Direitos Individuais Homogêneos, porque tidos como espécie dos Direitos Coletivos, desde que o seu objeto se revista da necessária relevância social. 3. A melhor interpretação do disposto no art. 34 da Lei 10.741/2003 (Estatuto do Idoso) conduz ao entendimento de que conquanto seu parágrafo único se refira especificamente a outro benefício assistencial ao idoso, não há como restringi-lo a tal hipótese, sendo de se aplicá-lo extensiva ou analogicamente quando verificada a existência de benefício assistencial concedido a familiar deficiente, ou benefício previdenciário de valor mínimo concedido a familiar idoso, seja o postulante idoso ou deficiente (...)" (TRF-4. ${ }^{a}$ Reg., AC 2005.72.05.001947-1, Turma Suplementar, j. 27.05.2009, rel. Ricardo Teixeira do Valle Pereira, DE 15.06.2009). 
Individuais Homogêneos, ao argumento de que nem a Lei Maior, no aludido preceito, nem a LC 75/1993, teriam cogitado dessa categoria de Direitos.

2. A Ação Civil Pública presta-se à tutela não apenas de direitos Individuais Homogêneos concernentes às relações consumeristas, podendo o seu objeto abranger quaisquer outras espécies de interesses transindividuais (STJ, REsp 706.791/PE, 6. ${ }^{\mathrm{a}}$ T., j. 17.02.2009, rel. Min. Maria Thereza de Assis Moura, DJe 02.03.2009).

3. Restando caracterizado o relevante interesse social, os Direitos Individuais Homogêneos podem ser objeto de tutela pelo Ministério Público mediante a Ação Civil Pública. Precedentes do Pretório Excelso e da Corte Especial deste Tribunal.

4. No âmbito do Direito Previdenciário (um dos seguimentos da Seguridade Social), elevado pela Constituição Federal à categoria de Direito Fundamental do homem, é indiscutível a presença do relevante interesse social, viabilizando a legitimidade do Órgão Ministerial para figurar no polo ativo da Ação Civil Pública, ainda que se trate de Direito disponível (STF, AgRg no RE 472.489/RS, 2. ${ }^{a}$ T., j. 29.04.2008, rel. Min. Celso de Mello, DJe 29.08.2008).

5. Trata-se, como se vê, de entendimento firmado no âmbito do STF, a quem a Constituição Federal confiou a última palavra em termos de interpretação de seus dispositivos, entendimento esse aplicado no âmbito daquela Excelsa Corte também às relações jurídicas estabelecidas entre os segurados da previdência e o INSS, resultando na declaração de legitimidade do Parquet para ajuizar Ação Civil Pública em matéria previdenciária (STF, AgRg no AgIn 516.419/PR, 2. ${ }^{a}$ T., j. 16.11.2010, rel. Min. Gilmar Mendes, DJe 30.11.2010).

6. O reconhecimento da legitimidade do Ministério Público para a Ação Civil Pública em matéria previdenciária mostra-se patente tanto em face do inquestionável interesse social envolvido no assunto, como, também, em razão da inegável economia processual, evitando-se a proliferação de demandas individuais idênticas com resultados divergentes, com o consequente acúmulo de feitos nas instâncias do Judiciário, o que, certamente, não contribui para uma prestação jurisdicional eficiente, célere e uniforme.

7. Após nova reflexão sobre o tema em debate, deve ser restabelecida a jurisprudência desta Corte, no sentido de se reconhecer a legitimidade do Ministério Público para figurar no polo ativo de Ação Civil Pública destinada à defesa de Direitos de natureza previdenciária.

8. Recurso especial desprovido." 27

27. STJ, REsp 1.142.630/PR, 5. ${ }^{\text {a }}$ T., j. 07.12.2010, rel. Min. Laurita Vaz, DJe 01.02.2011. 
No caso, tratou-se de Ação Civil Pública visando à revisão de benefícios previdenciários concedidos pelo INSS a partir de 1994, para incluir uma variação de 39,67\% no mês fevereiro de 1994 nos salários de contribuição no período base do cálculo. A ação foi julgada procedente em primeira instância e confirmada pelo TRF da 4. ${ }^{a}$ Região - Porto Alegre - limitando-se, entretanto, os efeitos do julgado à Subseção Judiciária de Curitiba (PR). Alguns aspectos de notável importância devem ser destacados na referida decisão: $1 .^{\circ}$ ) a inovação em permitir-se que os benefícios previdenciários possam ser revistos por meio de Ação Civil Pública; $2^{\circ}$ ) a proposição de que toda matéria de seguridade social seja vista como direito fundamental do homem e, por isso, portadora de relevância social; $3^{\circ}$ ) a caracterização do Direito à revisão de benefício previdenciário como um direito individual homogêneo; e $4^{\circ}$ ) que a Ação Civil Pública presta-se não somente aos Direitos Individuais Homogêneos Consumeristas, mas a qualquer Direito Transindividual.

No âmbito do STF, há decisão recente, da lavra do Min. Gilmar Ferreira Mendes (STF, AgRg no AgIn 516.419/PR, 2. ${ }^{\mathrm{a}}$ T., j. 16.11.2010, rel. Min. Gilmar Mendes, DJe 30.11.2010), que também manifesta entendimento favorável ao manejo da Ação Civil Pública para a revisão de benefícios. No caso, a Ação Civil Pública objetivou a condenação da autarquia à revisão da renda mensal inicial de benefícios previdenciários concedidos anteriormente à vigência da Lei Maior, com a correção dos 24 primeiros salários de contribuição integrantes do PBC pelos índices das ORTNs/OTNs/BTNs. Na argumentação do Min. Gilmar Mendes restou reconhecida "a legitimação ad causam do Ministério Público, assim para a tutela de interesses e Direitos Difusos e Coletivos - os Transindividuais de natureza indivisível -, como para a proteção de Direitos Individuais Homogêneos, sempre que estes, tomados em conjunto, ostentem dimensão de grande relevo social, ligada a valores e preceitos que, hospedados na Constituição da República Federal, sejam pertinentes a toda a coletividade. Nesses casos, a atuação do Ministério Público afeiçoa-se a seu perfil institucional, voltado ao resguardo do interesse social e dos Direitos Coletivos, considerados em sentido amplo (arts. 127 e 129, III e IX, da CF/1988)".

No que concerne ao Direito à Saúde, a questão já foi considerada de repercussão geral pelo STF, em pronunciamento assim ementado: "Saúde. Assistência. Medicamento de alto custo. Fornecimento. Possui repercussão geral controvérsia sobre a obrigatoriedade de o Poder Público fornecer medicamento de alto custo". Mas, em sede de Ação Civil Pública e sua relação com os Direitos Individuais Homogêneos não há pronunciamento encontrado. Merece atenção, ademais: 
"Direito Constitucional. Direito à Saúde. Agravo Regimental em Agravo de Instrumento. Implementação de políticas públicas. Ação Civil Pública. Prosseguimento de julgamento. Ausência de ingerência no poder discricionário do Poder Executivo. Arts. 2. ${ }^{\circ}, 6 .^{\circ}$ e 196 da CF/1988. 1. O Direito à Saúde é prerrogativa constitucional indisponível, garantido mediante a implementação de políticas públicas, impondo ao Estado a obrigação de criar condições objetivas que possibilitem o efetivo acesso a tal serviço. 2. É possível ao Poder Judiciário determinar a implementação pelo Estado, quando inadimplente, de políticas públicas constitucionalmente previstas, sem que haja ingerência em questão que envolve o poder discricionário do Poder Executivo. Precedentes. 3. Agravo regimental improvido" (STF, AgIn 734.487/PR, 2. ${ }^{a}$ T., j. 03.08.2010, rel. Min. Ellen Gracie, DJe 20.08.2010).

Assim, destacamos alguns aspectos que constam nas decisões do STF: $1 .^{\circ}$ ) o Direito à Saúde vem sendo considerado um Direito Indisponível cabendo ao Estado a obrigação de assegurá-lo; $2^{\circ}$ ) o Poder Judiciário não ofende o Princípio da Separação dos Poderes quando impõe a implementação de políticas públicas, uma vez que dimanam de ordem constitucional; $3 .^{\circ}$ ) o Direito à Saúde é um Direito Prestacional Social, exigível "impostergavelmente" com base no art. 196 da CF/1988 (STF, AgRg na STA 175, Pleno, j. 17.03.2010, rel. Min. Gilmar Mendes, DJe 30.04.2010).

Diante dessas características, com base nos precedentes do STF, fica patente a possibilidade de exigibilidade judicial de prestações referentes ao direito à saúde. Com essas qualificações dogmáticas, resta por concluir que a Ação Civil Pública é o instrumento idôneo, eficaz e econômico para a postulação judicial dos Direitos Coletivo em sentido amplo, incluindo-se aí os Direitos Individuais Homogêneos.

\section{ConclusÃo}

Por todo o exposto, nota-se quão judiciosa é a lição de Marcelo Cattoni (2002, p. 115) ao questionar a validade de modelos interpretativos e semânticos rigorosos. Para ele a fixação de conceitos abstratos fora do contexto de aplicação e a extensão de sentido dos textos normativos devem ser abandonados. Modelos interpretativos, diz o autor, são bem-vindos para reduzir a complexidade interpretativa, porém, devem sempre ser abertos e passíveis de revisão.

“(...) dizer, por exemplo, que o Ministério Público não poderá defender Direitos a não ser os Coletivos e Difusos, nunca os Individuais Homogêneos, que os Direitos Coletivos e Difusos são tais ou quais, previstos nos artigos tais, 
fixados numa lista fechada ou só defensáveis em única perspectiva, é reduzir as possibilidades de acesso à jurisdição e negar, de antemão, a tutela jurisdicional, através de meio processual, que poderá ser o coletivo, cuja adequação só poderá ser analisada caso a caso, como questão endoprocessual" (CATTONI, 2002, p. 115).

As possibilidades evolutivas quanto à aplicação dos Direitos Fundamentais Sociais, portanto, dependem sempre de uma abertura conceitual suficiente para que os Direitos Materiais não sejam sufocados por questões processuais de menor importância.

Os Direitos Fundamentais Individuais homogêneos são "princípios", portanto, mandados de otimização. Devem, assim, ser cumpridos na maior medida possível dentro das possibilidades fáticas e jurídicas existentes.

“(...) a questão acerca de quais Direitos Fundamentais Sociais o indivíduo definitivamente tem é uma questão de sopesamento entre princípios. De um lado está, sobretudo, o Princípio da Liberdade Fática. Do outro lado estão os Princípios Formais da Competência Decisória do Legislador Democraticamente Legitimado e o Princípio da Separação dos Poderes, além de princípios materiais, que dizem respeito sobretudo à liberdade jurídica de terceiros, mas também a outros Direitos Fundamentais Sociais e a interesses coletivos."

Assim, sempre existirá essa tensão principiológica quanto às diferentes possibilidades de efetivação dos Direitos Fundamentais. Num primeiro momento cabe ao legislativo proceder ao exame de proporcionalidade no que diz respeito aos meio empregados ao cumprimento de determinada tarefa.

No caso de proteção insuficiente por parte de que tem o dever constitucional de efetivar um Direito Social (seja ele Individual Homogêneo ou não), abre-se a possibilidade de justicialização. Nesse passo, é razoável que os meios processuais cabíveis para a reivindicação cidadã desses Direitos seja ampla e acessível, abrindo-se a possibilidade de novo exame da proporcionalidade da pretensão para o caso concreto. Muito ainda se pode evoluir em matéria processual para que a tutela dos Direitos Fundamentais seja ampla e mais efetiva.

\section{BibliografiA}

Abramovich, Victor; Courtis, Christian. Los derechos sociales como derechos exigibles. Madri: Trotta, 2004.

Alexy, Robert. Teoria dos direitos fundamentais. São Paulo: Malheiros, 2008.

Almeida, João Batista de. Aspectos controvertidos da ação civil pública: doutrina e jurisprudência. Prefácio de J. P. Sepúlveda Pertence. São Paulo: Ed. RT, 2001.

Boвbio, Norberto. A era dos direitos. Trad. Carlos Nelson Coutinho. Rio de Janeiro: Elsevier, 2004. 
Canotilho, José Joaquim Gomes. Direito constitucional: teoria e Constituição. 7. ed. 10. reimp. Portugal: Almedina, 2011.

; Moreira, Vital. Fundamentos da Constituição. Coimbra: Coimbra Ed., 1991.

Cappelletti, Mauro; Garth, Brian. Acesso à Justiça. Porto Alegre: Fabris, 1988.

Cattoni, Marcelo. Direito constitucional. Belo Horizonte: Mandamentos, 2002.

Dinamarco, Pedro da Silva. Ação civil pública. São Paulo: Saraiva, 2001.

Freitas, Juarez. A interpretação sistemática do Direito. 5. ed. São Paulo: Malheiros, 2010.

. O controle dos atos administrativos e os princípios fundamentais. 4. ed. São Paulo: Malheiros, 2009.

Gadamer, Hans-Georg. Verdade e método I: traços fundamentais de uma hermenêutica filosófica. Petrópolis: Vozes, 2007.

Grinover, Ada Pellegrini. Código Brasileiro de Defesa do Consumidor, comentado pelos autores do anteprojeto. 8. ed. Forense: Rio de Janeiro, 2004.

GuEdes, Jefferson Carús. Direito processual social no Brasil: as primeiras linhas. Revista de Processo. vol. 142. p. 137-167. São Paulo: Ed. RT, dez. 2006.

Maccormick, Neil. Argumentação jurídica e teoria do direito. São Paulo: Martins Fontes, 2006.

Mancuso, Rodolfo de Camargo. Interesses difusos: conceito e legitimação para agir. 6. ed. rev., atual. e ampl. São Paulo: Ed. RT, 2004.

Marinoni, Luiz Guilherme; Arenhart, Sérgio Cruz. Procedimentos especiais. São Paulo: Ed. RT, 2009.

Martins, Ives Gandra da Silva. Ação civil pública é veículo processual imprestável para proteção de direitos individuais disponíveis. Revista dos Tribunais. vol. 707. p. 19-32. São Paulo: Ed. RT, set. 1994.

Mazzilli, Hugo Nigro. A defesa dos interesses difusos em juízo: meio ambiente, consumidor, patrimônio cultural, patrimônio público e outros interesses. 20. ed. rev., atual. e ampl. São Paulo: Saraiva, 2007.

Megaré, Plínio. Um olhar sobre os direitos fundamentais e o Estado de Direito - Breves reflexões ao abrigo de uma perspectiva material. In: SARLET, Ingo Wolfgang (org.). Jurisdição e direitos fundamentais. Porto Alegre: Livraria do Advogado, 2006.

Milhoranza, Mariângela Guerreiro; Tesheiner, José Maria Rosa. Direitos indisponíveis e legitimação do Ministério Público para as ações coletivas relativas a direitos individuais homogêneos de natureza previdenciária. Revista de Processo. vol. 172. p. 9-18. São Paulo: Ed. RT, jun. 2009.

Neurer, Jörg. Os direitos sociais humanos. In: SARLEt, Ingo Wolfgang (org.). Jurisdição e direitos fundamentais. Porto Alegre: Livraria do Advogado, 2006.

Perlman, Chaim \& Olbrechts-Tyteca, Lucil. Tratado de argumentação: a nova retórica. São Paulo: Martins Fontes, 1996. 
SARLET, Ingo Wolfgang. A eficácia dos direitos fundamentais. 10. ed. rev., atual. e ampl. Porto Alegre: Livraria do Advogado, 2010.

Constituição e proporcionalidade: o direito penal e os direitos fundamentais entre a proibição de excesso e de insuficiência. Revista da Ajuris. n. 98. ano XXXII. Porto Alegre: Ajuris, jun. 2005.

(org.). Jurisdição e direitos fundamentais. Porto Alegre: Livraria do Advogado, 2006.

Siqueira Júnior, Paulo Hamilton. Direito processual constitucional. 3. ed. São Paulo: Saraiva, 2009.

Souto, Marcos Jurena Villela. Neoconstitucionalismo e controle de políticas públicas. In: Quaresma, Regina; Oliveira, Maria Lúcia de Paula; Oliveira, Farlei Marcins Riccio de. Neoconstitucionalismo. Rio de Janeiro: Forense, 2009.

Strapazzon, Carlos Luiz. Responsabilidade judicial e interpretação dos direitos sociais. In: Baez, Narciso L. X.; Leal, Rogério G.; Mezzarobba, Orides (orgs.). Dimensões materiais e eficaciais dos direitos fundamentais. São Paulo: Conceito, 2010.

Sunstein, Cass R. A constituição parcial. Del Rey: Belo Horizonte: 2009.

Social and economic rights? Lessons from South Africa. $U$ of Chicago, Public Law Working Paper n. 12; U Chicago Law E Economics, Olin Working Paper n. 124, may 2001. Disponível em: [http://ssrn.com/abstract=269657]. Acesso em: 25.10.2011.

TORRES, Ricardo Lobo. O direito ao mínimo existencial. 2. tir. Rio de Janeiro: Renovar, 2009.

Tulmin, Stephen. Os usos do argumento. 2. ed. São Paulo: Martins Fontes, 2006.

Zavascki, Teori Albino. Processo coletivo - Tutela de direitos coletivos e tutela coletiva de direitos. São Paulo: Ed. RT, 2006.

\section{Pesouisas do Editorial}

\section{Veja também Doutrina}

- Ação civil pública é veículo processual imprestável para proteção de direitos individuais disponiveis, de Ives Gandra da Silva Martins - RT 707/19;

- Direito processual social no Brasil: as primeiras linhas, de Jefferson Carús Guedes RePro 142/137; e

- Direitos indisponíveis e legitimação do Ministério Público para as ações coletivas relativas a direitos individuais homogêneos de natureza previdenciária, de José Maria Rosa Tesheiner e Mariângela Guerreiro Milhoranza - RePro 172/9. 